Catherine Caufield

\title{
Landscapes of Trauma and Transformation: Poems of Anne Michaels, Karen Shenfeld, and Miriam Waddington
}




\section{Abstract}

Long before ecocriticism became a focus for textual analysis, poets articulated interconnection with the natural world. Not only green but vibrant colour across the spectrum has semiotically served poets as they sought to venture ever deeper into understanding the expanse of human experience and the anguish that all too often accompanies it. The idea of post-traumatic transformation is rooted in the Hebrew Bible and in the contextual stories with which it is intertextually connected. Casting out the idea that hardship is intentionally imposed for the express purpose of causing growth, the fact remains that suffering-sometimes unbearable suffering-is integral to human life and we must grapple with it. The colourful imagery and synesthesia of landscape can be leveraged descriptively and metaphorically to express pain, confusion, and questioning. Traversing the terrain of confounding events, poetic poesis of the works analyzed in this article demonstrates a wrestling to find, however provisionally, transformative trails through the wreckage.

\section{Résumé}

Bien avant que l'écocritique ne devienne un focus pour l'analyse textuelle, les poètes ont articulé l'interconnexion avec le monde naturel. Plus que la couleur verte, tous les tons à travers le spectre ont servi sémiotiquement les poètes alors qu'ils cherchaient à s'aventurer toujours plus profondément dans la compréhension de l'étendue de l'expérience humaine et de l'angoisse qui l'accompagne trop souvent. L'idée de transformation post-traumatique est enracinée dans la Torah et dans les histoires contextuelles avec lesquelles elle est intertextuellement connectée. En rejetant l'idée que la souffrance est intentionnellement imposée dans le but de provoquer la croissance, il n'en reste pas moins que la souffrance-parfois insupportable-fait partie intégrante de la vie humaine et nous devons la combattre. L'imagerie colorée et la synesthésie du paysage peuvent être exploitées de manière descriptive et métaphorique pour exprimer la douleur, la confusion, et le questionnement. Traversant le terrain d'événements déroutants, la poésie poétique des auvres analysées dans cet article démontre la lutte pour trouver, même provisoirement, des pistes transformatrices à travers les épaves.

Canadian Jewish landscape is soaked in suffering; much of it is traumatic, much of it originates in Europe and beyond. This suffering is embalmed in millennia-old story which reverberates through generations and continues in experiences of anti-Semitism on our liberal democratic Canadian shores. Trauma "originates in the shock for which the psyche is unprepared." That shock may locate itself in the amygdala, giving it conscious memory, but often in shattered ways such as nightmares and flashbacks. It may also lie buried in the hypothalamus, "safely" out of reach of the sense-making cerebral cortex. Trauma is thus "an experience that is not experienced, that resists or escapes consciousness." This gap, a kind of dead space, between 
horrific experience and the recognition of what it is that is affecting the psyche, is sometimes referred to as the traumatic impasse.

The challenge for healing, for regaining the ability to engage with life and feel joy once again, is how to connect with what has been repressed (in order to keep the ego safe and thus able to function well enough in day-to-day life) and, slowly and incrementally, give it voice. Bringing to light that which has been hidden opens possibility for shifts in perspective, psychic integration of past trauma, and (re)connection with self and others. Poetry, as much of art, provides access to those hidden recesses of non-verbal, unarticulated, experience. The creative act of writing poetry can serve to bring to consciousness; in the act of reading poetry, the reader, too, is "drawn into the territory and subsumed into a process of increasing self-awareness through the projection and identification."3 Leaning heavily on the seminal work of Simon Schama, ${ }^{4}$ this essay explores several examples of poems by Canadian Jewish women that reference landscapes of various kinds. As Panofsky eloquently elaborates in her comments on three protagonists: "Stories of deep suffering and rallying resistance - such as those of Esther Brandeau, ${ }^{5}$ Miriam Entelman, ${ }^{6}$ and Annetter Gershon ${ }^{7}$ - affirm the durable 'difference' of Jewish cultural identity in the Canadian

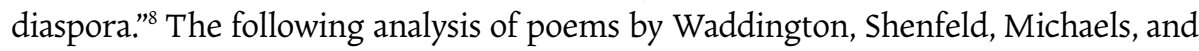
Tregebov bring stories of deep suffering to consciousness, using landscape tropes and referents. Further, they leverage those landscapes in integrating emotional pain to evidence teshuva, the possibility of turning, again, to life.

In Landscape and Memory, Simon Schama argues that "landscapes are culture before they are nature; constructs of the imagination projected onto wood and water and rock [.. . ] once a certain idea of landscape, a myth, a vision, establishes itself in an actual place, it has a peculiar way of muddling categories, of making metaphors more real than their referents; of becoming, in fact, part of the scenery"9 This theoretical perspective makes it possible to understand horrific events happening on bright, sunny days in bucolic settings: there is nothing implicit or pure or inherent in the topography - these qualities are narrated in. "The word [landscape] entered the English language," Schama records:

as a Dutch import at the end of the sixteenth century. And landschap, like its Germanic root, Landschaft, signified a unit of human occupation, indeed a jurisdiction, as much as anything that might be a pleasing object of depiction. [...] But in the Netherlands, the human design and use of the landscape-implied by the fishermen, cattle drovers, and ordinary walkers and riders who dotted the paintings of Esaias van de Velde, for example-was the story, startlingly sufficient unto itself. ${ }^{\circ}$ 
By its etymology then, the word landscape means creating shape and contour. That which is landscaped has been changed. Landscapes are human-made places, sculpted from land and lands to which people are rooted, to which they belong, to which they are connected.

Schama is referring to physical form; by contrast, A. M. Klein in his "Portrait of the Poet as Landscape" ${ }^{\text {"II }}$ laments the situation, the landscape, of a poet who, although he "unrolled our culture from his scroll-/ the prince's quote, the rostrum-rounding roar-/ who under one name made articulate / heaven" ... his work is ignored. He is unhappy; he feels an imposter to himself.

Landscape, landscaping, whether physical or imaginative, is intentionally designing and ordering elements in the natural world. Despite "sometimes, [being] depressed to nadir" from the lack of recognition, the poet in Klein's piece obstinately remains a "nth Adam taking a green inventory / in world but scarcely uttered, naming, praising" - despite the dismal landscape of those who "know neither up nor down, mistake the part / for the whole, curl themselves in a comma." Intentionally designing and ordering "is breath / to him [...] air to his lungs, and pressure blood to his heart,-/ they are pylsates, and breathed, until they map, / not the world's, but his own body's chart!" By part IV of "Portrait of the Poet as Landscape" the poet is no longer an imposter to himself and now, from within, he recognizes a rich garland: the flowers are there if you wish to pick them (albeit, he concludes, still feel at the bottom of the sea).

Landscapes are large and as such they provide a view, a picture, a macroscopic perspective - "the better to look," as Klein's poet writes. Landscapes are not static; they change over time. The Jewish Canadian women who penned the poems considered here have referenced landscapes that are both rural and urban. "Before it can ever be a repose for the senses," Schama writes, "landscape is the work of the mind. Its scenery is built up as much from strata of memory as from layers of rock."12 The poems included here do not provide repose for the senses. Yet, Schama's research and theoretical understandings are useful because he has "suggest[ed] a new way of reading landscape, by removing it from the category of 'nature' and demonstrating the extent to which it is culturally invested. His project rests on the assumption that nature and culture are not mutually exclusive categories. From the strata of each author's imagination, what do these poems project with regard to the landscape of trauma and healing - and how are those projections constructed.

"The poem," writes Miriam Waddington, "should tell us something we didn't know before we read it. The something that it tells us should have [.. . ] a threefold impact on the reader; physical, emotional, and intellectual."' Written in the wake of the Second World War, Waddington's "Green World"14 evokes a natural environment, using figurative language to express sensory knowing: 
When I step out and feel the green world Its concave walls must cup my summer coming And curving, hold me Beyond all geography in a transparent place Where water images cling to the inside sphere Move and distend as rainbows in a mirror Cast out of focus.

And this crystal chrysalis Shapes to green rhythms to long ocean flowings Rolls toward the sun with sure and spinning speed And under the intensely gold point Warms, expands, Until walls crack suddenly Uncup me into large and windy space..$^{15}$

The speaker feels life: the green, living world. The delight in this is expressed through resonant assonances: feel and green, summer and coming, and others. Fluid images flutter, out of focus. The challenge for the poet is how to give form to these floating fragments. Notice the hard " $\mathrm{c}$ " in the choice of words such as cup, cast, concave, crystal. The " $c$ " itself is concave, protective; the curving walls of the green world provide a container for-cup - the experience of the writer. The harshness of this sound gives way to shaping flowing rolling, distorted rainbows clinging in some geography-less bounded place; then: cracks open. The speaker's stepping out into feeling is contained by the contours of her creative capacity, a place beyond geography.

Yet the very components of this "crystal chrysalis" - the images and rhythms that the poet uses to give form to feeling - move her into unbounded, "uncupped," space. This space does not have the satisfaction of having answers; it is not a tranquil place. It is windy, and large, like an expanse of prairie. The image of "cup," of being inside the walls of a container, connotes being surrounded by something solid and safe. As metre and metonymy bring understanding into focus at the brink of two caesurae, the writer finds herself outside of physicality; she finds herself in the space of ru'ach: wind, life breath - spirit.

Waddington has leveraged landscape metaphorically; Karen Shenfeld connects with the visceral physicality of it. Included in a collection of poetry titled My Father's Hands Spoke in Yiddish, "Canoeing Song"16 depicts a speaker seated in the bow of a canoe, paddling across a calm freshwater lake at dawn. The imagery is vivid, the scene devoid of colour and movement: "trees rendered en grisaille," the shadow of the canoe darkening the rocks rising along the shores as two figures pause and drift. The nothingness evoked here is rent, simply, by the cry of a loon: a wistful, haunting sound. 
The canoe is a Canadian symbol; the words cottages, trees, and granite boulders evoke the lakes pooled in the igneous rock of the Canadian Shield. This geological formation stretches from the northwestern tip of Alberta to the easternmost edges of Labrador and up into the islands of the Arctic. Yet "cottage country" is a term particular to Ontario, generally referring to Muskoka, Haliburton, the Kawarthas, and sometimes the Rideau Lakes region. The mention of cottages and the naming of $\mathrm{E}$. Pauline Johnson [Tekahionwake], the famous Mohawk-Canadian poet, clearly locates the poem in the space of Ontario; time, however, is equivocal. Is the speaker actually canoeing with the Mohawk woman, or is there a temporal palimpsest in which the speaker anachronistically imagines this historical figure guiding her canoe, a kind of nostalgia permeating the poem.

Shenfeld's enjambment of:

across the gunwales, blades raining

freshwater pearls; beneath the depths

carries the idea of the continuity of the physical canoe beyond the restriction of a single line of written words, beyond the separation of wood and water. Liquid depths connote the subliminal, the present but unannounced interface between Mohawk poet and Yiddish father; two sources of home, of location and connection, integrated through hands. The hands that spoke in Yiddish; the hands that grasp the shaft of the paddle. Hands that direct the canoe home, an echo of the father's hands. A palimpsest chronotope of handed down, the past in the present, different hands in the same land; the laying on of hands as blessing.

The granite boulders meld the human with the geological; mute rock animated once the Jewish paddler reflects on it, enlivening it through language and emotion. $\mathrm{Hu}-$ man connection, indigenous and immigrant, drifting on pools formed from glacial erosion edged by rock fired in the depths of the Archeon eon. Two women, inextricably linked to a landscape that was shaped in the oldest of eras, the pre-human Precambrian. Paddle-wings take the canoeists in tandem, one stroke at a time, to creating, or echoing, a lived liquid song framed in a geological history "coughed up from earth's bright core." The speaker of the poem clearly resonates with the beauty of an iconic Canadian landscape - the northern lakes, rocks, and forests. A feeling of harmony, of oneness, permeates the poem. At-onement, integral to reconciliation when there has been a rift. The contemporary Torontonian author of the poem acknowledges a reciprocity between cultural rootedness and deep connection to longago songs still sung ... when mists lift, when consciousness clears, just a few paddle strokes from cottage-lined shores. 
The analysis of the two poems above has assumed that there is a relationship between the internal world of the poem and the external world existing outside of it. However, the idea of poetic language articulating with extratextual referentiality is a contested assumption. The Romantics and late nineteenth century French symbolists insisted that while certainly intertextuality is valid, desirable even, in the analysis of verse, the poetic context precludes extratextual reference. This position was enhanced through arguments made by I. A. Richards and the New Critics during the I920s, in tandem with Russian formalists, asserting the autonomy of poetic language. Poststructuralists of the I980s too, posited a referential fallacy based on semiotic understandings of literary interpretation, pitting the aesthetic beauty of the language of poetry that the Romantics insisted upon against the plain language of science that the structuralists and naturalists who ushered in the modern period insisted upon.

In contrast, Walter Sutton rebuts: "the referential function of words-far from being alien to the poem or novel-actually contributes to its aesthetic effect and to its formal integrity."17 This line of interpretation, while diminished in stature during the I970s and I980s, was nevertheless not lost. Although "we move beyond the purely mimetic in reading," Linda Hutcheon acknowledges, "we never manage to eradicate it completely." Writers themselves attest to this connection between the inner world of the poem and the outer world in which the literary work is located: "The art work transforms the artist and creates him at the same time as he transforms the world by his recreation of it through his work. Thus there is a continuous interchange between inner and outer, and a continuous relation between self and world."19

Referential relationship is integral to analyses that postulate transformational possibility in the acts of writing and reading. Anne Whitehead, a key contemporary academic working in the area of fiction and trauma, explains that "the process of viewing a landscape is one of careful construction, through which the indifferent or unaccommodating space of a site or environment is transformed into a place which draws the viewer into its territory."20 It is this transformation from space to place, this bringing to consciousness and naming, that opens possibility for changes in perspective that are needed to move through suffering.

In Anne Michaels' "Lake of Two Rivers" an existing location in Algonquin Park becomes a place mediated through poetry, drawing the reader into its territory, joining past and present. The first section of "Lake of Two Rivers" begins with a line and two couplets. Water, imperatively pulled open and unhooked at its seam, recalls the rupture of the peaceful amniotic sac and dilating cervix at birth. Water, that which has the power to profoundly shape any landscape. Written in the imperative mood, the speaker observes a past iteration of itself lie down in the redolence of new leaves in a watery room and, passively, fall asleep-in the slow, steady way the moon makes its orbit in the heavens. The last section of the poem ends with three couplets, writ- 
ten in the indicative simple present. The new leaves are now a forest blown apart, the water is now tears, and the word moon, replaced by the word love, does not fall, a downward motion, but rather actively bursts upward from the earth. The lesser light of the moon provides light in the light, like birth from darkness. Through the earthy ravages of life being lived, love, deeply rooted, develops. The intervening three sections, of various stanzaic lengths, enjambments, and diverse punctuation marks, evoke a landscape of familial relationships that move the reader from an "in the beginning" moment to a poetic present.

An oneiric quality pervades this poem, as it does so much of Michaels's work. Form connects with content as fragments of memory and rumination intermingle. Section two juxtaposes the tale of the utopian Shangri-La depicted in the eponymous 1937 American movie with the story of the dystopian Poland experienced by her father in the 1930s. The father tells his stories to the nuclear family contained within the 1964 Buick, his lost extended family forever barred from connecting with the life held safe within the moving vehicle. As the Buick wends its way north through the Canadian night, "the moon fell into our car from Grodno." The darkness of Eastern Europe ${ }^{22}$ embalmed in transnational lunar light, is being carried forward by story; in its articulation it is formed and reformed, transformed by new tellings, deeper understandings.

Section three melds the human with the weather. A play of light wherein the lightness of a name is as elusive as physical light. In this section of the poem the reader is made aware that the speaker is plural: "we" is on the shores of the Lake of Two Rivers, "linked by firelight" to the lake, its fish, its trees, the moon above and the farmers' fields beyond. Whitehead observes that "Michaels's writing tentatively revives the notion of a reciprocal and potentially healing bond between man and nature."${ }^{23} \mathrm{Re}-$ ciprocal healing potential is expressed through melding human and nature, but too this section reflects a longing to gather the shards of light, making whole all that was broken. An understanding of trauma recovery is referenced by Whitehead in her comment that "redemption or healing, in so far as it is envisaged to be possible, is conceptualised as a process of gathering up dispersed fragments and piecing together the past." ${ }^{24}$ Consistent with this understanding of a key aspect of post-traumatic stress disorder, the sense of having lost parts of oneself, Whitehead continues: "for Michaels, [. . . the gathering of the fragments carries a redemptive import and leads to a fleeting or momentary illumination or revelation." 25 The light reflected in "Lake of Two Rivers" refracts both to individual trauma and to a Lurianic conceptualization of the underlying cause of such profound pain in the material world.

Section four opens with memory of mother, and mother's memories: "this domestic love is pain, hurts / the way light balancing objects in a still life hurts." The speaker's mother is still, dead. "Light limited, light specific / light like a name" and light in 
lifeless form. Sensate, "love wails from womb, caldera, home / Like any sound, it goes on forever." The physical body remembers: "the eyes of our skin won't close." An asterisk shifts this reverie and the desire for mother blends with sexual desire; the poetic "we" is two. The "unhooked seam" becomes "the seam between starlight and skin," intercourse the connection to infinity.

In section five, the last section, the speaker has gone to Poland. She has gone to the banks of the river in the father's long-ago stories told to his family in the car moving through the Canadian night. "Faces press the transparent membrane / between conscious and genetic knowledge" recalls the first section of "Lake of Two Rivers," echoing its allusions to birth. Now it is the speaker who is on the outside, "a face pressed against a window," a voyeur to the lives of lost family. Yet shards of light are gathered: "we are a family now" an imperfect vessel evoking a tableau of unrealized relationships pieced together as best as possible.

"No longer exclusively a phenomenon of nature, landscape is a site that has been modelled by history"26 states Whitehead. This dynamic is evidenced in the poems by Michaels and Shenfeld and the way in which each evokes an external referent and use figurative language to leverage that referent to create meaning. Both integrate elements of rural Canadian landscape, water in particular, as filled with redemptive potential. Water-rivers and lakes-space that becomes a place of recognition of global interconnection, of continuity between past and present. Liquid external empirical physicalities through which inner landscapes clarify, knowledge and understanding deepen. Yet, as Whitehead cautions, "maintain a balance between preserving the past and becoming silted up or clogged with memory."27

In her comments on the work of Geoffrey Hartman, one of the pioneers in the development of trauma theory in a literary context, Whitehead notes that "on encountering a particular site, the viewer must find her bearings in relation to it, in order to fulfil the demands of landscape [.. .] this emphasis on landscape as a process of positioning is crucial to a consideration of the connection between landscape and trauma."${ }^{28}$ The importance of how we see, from what vantage point we see, has been a methodological consideration since Kant's Inaugural Dissertation in $1770 .^{29}$ Such a perspective reflects the interpretation of literature itself; what Paul Ricoeur would call the prefigurative, what it is that one brings a priori into the process of interpretation. As evidence from the past is concealed within the visible panoramas that lay before us, so too is that which an interpreter brings to a work often also concealed. Part of the hermeneutic task, as with trauma healing, is to illuminate these hidden areas.

In a parallel to Ricoeur's hermeneutics of sedimentation (tradition) and innovation, Waddington creatively casts the Pesach story onto a contemporary urban landscape. The plural speaker in "Traffic Lights at Passover" navigates the streets of Montréal, 
"gulp(ing) the gas fumes of the air," questioning whether the Israelites did, spiritually and psychologically, pass through the parted waters of the Red Sea. The poet determines that they did not. They were unable to "transcend [. . . / this dryness which no sense can irrigate," unable to "cross our mountainous griefs." Through the (now) "unfamiliar" prayers of Pesach, the "we" of the poem is condemned to live another year-rather than rest "firm upon the wings / Of the forgotten angel, death." Wholly exiled from the faith of the ancestors, "the open door was left / untranslated for Elijah's coming" and thus the import of Judaism for younger generations goes unrecognized, has no meaning in the language of modern youth.

As the traffic light changes, the speaker "send[s] our Hebrew God this alien prayer:" to be led from "misplaced faith" to Christmas (Mayflower wreath) and Easter (white paschal lamb) and, in this petition made during Pesach, for "a single leavened hour." An elegy for exile from meaningful religious practice, "Traffic Lights at Passover" exudes disconnection and resignation as the car moves through the city air.

Waddington and Tregebov integrate elements of urban Canadian landscape, air in particular, as gray and contaminated; hardly redemptive qualities..$^{30}$ These figurative depictions resonate with non-fiction (non-poetic) works that bring to consciousness the incongruity between bright sun and peaceful, pastoral vistas-and the historical events that were lived there in flesh and blood..31 As the speaker in "Elegy for the Given" ${ }^{22}$ walks down Bathurst Street in Toronto, "the air is grey and smells [. . .] of exhaust, burnt toast, ozone, alyssum." Alyssum exudes the only agreeable odour in the grey air.

Another flower appears in "Elegy for the Given": The Rose of Sharon. As the bush is in flower, summer must be well advanced as that is when this plant produces its yield. The Rose of Sharon which "blooms mauve to the south and white to the north" in Tregebov's poem echoes the fecund female voice in the biblical text. Located at the entryway to a retirement home on Bathurst, the bush evokes recognition of the trajectory from youth to old age and an implicit lament for the passing of the flowering of youth.

As the speaker moves through the cityscape in "Elegy for the Given" a melange of unknown languages surges around her and a stereotypical urban lack of moral concern for humanity swells as the poem progresses. The speaker notes the man lying in his vomit - "I walk by" - the middle-aged man selling an evangelical magazine - "all of us walk by" - and the young man with a ring in his eyebrow - "amidst the cursing drivers." The raggedness of the poetic lines evokes a mimetic fraying at edges, reflecting in form the content of lives damaged, distorted, unrealized. Yet the very concreteness of language creates a vividness and a luminosity of souls navigating the life that has been given to them. While Waddington's poem exemplifies a par- 
ticular disconnection, Tregebov's exposes many. "Traffic Lights at Passover,"33 however reluctantly, reconciles with the given, shifting into gear when the traffic light changes, flowing along with all the other "cars like pastel lozenges." "Elegy for the Given," on the other hand, does not. Rather, it offers, ironically, an astounding, banal, array of toothpastes - there are choices as a salve for suffering; but these choices are not transformative ones.

The concreteness of culture creates connection as the speaker of Waddington's "Lately I've been Feeling Very Jewish,"34 vividly weaves remnants of history into present time. The poet makes overt reference to herself and Jews through a parallel structure that leaves the word "soft" exposed at the end of each of the first two lines of the poem: "Jews are soft / touches: I'm a soft / touch too." The enjambment reinforces this connection without caesura, without pause. The tempo of the short lines moves the reader rapidly to the end of the poem and an implied simile inverts the relationship postulated in the opening three lines. We see again the presence of water, the quality of melting which shapes the inner landscape of the poet; this contrasts with the frigid temperatures of February in most of Canada, even if the snow is receding just a little bit. The speaker reveals herself: "patches of bare earth," open to reciprocal connection with others. The yellow of the daffodil, which does not bloom in southern Ontario until late April, blends synesthetically with the sensibility of feeling and seeing. Jews are soft, the speaker is soft, the daffodil is soft. Touch permeates the poem, consistently combined with softness and Jewishness, subverted in the closing lines of the poem:

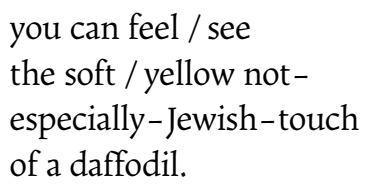

The speaker opened with a connection between herself and Jews. She closes with a rupture, a shift in voice from first person to second: "you" can both feel and see the daffodil, which makes "the world / less lonesome." Although that soft, yellow touch is, ironically, not particularly Jewish.

In the poems examined above a palimpsest of times and places emerges as humans (sometimes particularly Jewish) in urban and rural landscapes locate themselves in a present time that connects, simultaneously, with other landscapes and other times. These poems respond to "the challenge [in trauma recovery] [.. .] bring[ing] the past into constellation with the present, so that the remnants of history are not inert but assume a living force and a significant relation to contemporary events." ${ }^{35}$ Each poet is moved by signs of life, each evokes bodily senses in seeking to identify and to integrate pain and loss and suffering. Water and air, prime elements needed for 
human life, weave through the poems. The sound of a canoe paddle on a gunwale, the crackle of a fire on a lakeshore, the bloom of a flower: these elements within a landscape evidence teshuva, the possibility of turning again to life, even amidst an aching emptiness and utter ugliness.

1

Anne Whitehead, "Geoffrey Hartman and the Ethics of Place: Landscape, Memory, Trauma," European Journal of English Studies 7, no. 3 (2003): 283.

\section{2}

Cathy Caruth and Geoffrey Hartman, "An Interview with Geoffrey Hartman," Studies in Romanticism 35, no. 4 (1996): 631.

3

Whitehead, 292.

4

Simon Schama, Landscape and Memory

(Toronto: Vintage, 1996).

5

Susan Glickman, The Tale-Teller (Markham, ON: Cormorant, 2012).

\section{6}

Nancy Richler, Your Mouth is Lovely (New York: Ecco, 2003).

7

Rhea Tregebov, The Knife Sharpener's Bell (Regina: Coteau, 2009).

\section{8}

Ruth Panofsky, "'Sparks that Reach Far into the Past and Spin Toward the Future': The Historical Turn in Recent Novels by Susan Glickman, Nancy Richler, and Rhea Tregebov." Studies in American Jewish Literature 32, no. 2 (2016): 231.

9

Schama, 61.

\section{0}

Schama, 10. See also Susan Glickman, The Picturesque and the Sublime: A Poetics of the Canadian Landscape (Montréal and Kingston: McGill-Queen's University Press, 1998). Glickman documents the word "landscape" appearing in the English language in Holland around 1598 (ix) and in England by 1700 (4), although she notes John Denham's poem "Cooper's Hill" (1642) with its external referent of landscape to present allegory of societal hierarchy (5-6).

11

A. M. Klein, "Portrait of the Poet as Landscape," in Complete Poems. Part II: Original Poems 1937-1955. Edited by Zailig Pollock (Toronto: University of Toronto Press, 1990 [1948]), 634-639.

12

Schama, 6-7.

13

Miriam Waddington, "Poetry as Communication," Apartment Seven (Oxford: Oxford University Press, 1989 [1983]), 167.

\section{4}

Miriam Waddington, "Green World," in Green World (Montréal: First Statement, 1945).

15

Waddington, 1.

\section{6}

Karen Shenfeld, "Canoeing Song," in My Father's Hands Spoke in Yiddish (Montréal: Guernica, 2010), 54-55.

\section{7}

Walter Sutton, “The Contextualist Dilemma. Or Fallacy?" The Journal of Aesthetics and Art Criticism 17, no. 2 (1958): 221.

\section{8}

Linda Hutcheon, "Metaphysical Implications for Novelistic Reference," in On Referring in Literature. Edited by Anna Whiteside and Michael Issacharoff (Bloomington: Indiana University Press, 1987), 9. See also three-fold mimesis in Paul Ricoeur, Time and Narrative, volume 1 (Chicago: University of Chicago Press, 1984). 
19

Miriam Waddington, "Form and Ideology" in Apartment Seven (Oxford: Oxford University Press, 1989 [1978]), $162 f f$.

\section{0}

Anne Whitehead, Trauma Fiction. (Edinburgh: Edinburgh University Press, 2004), 48.

\section{1}

Anne Michaels, "Lake of Two Rivers," in The Weight of Oranges. 9-15. Toronto: Coach House, 1985), 9-15.

\section{2}

"One of [Rokhl] Korn's only poems that mentions Canada explicitly does so only in its title: "Indiyaner zumer in kanader berg" (Indian Summer in the Canadian Mountains, in Fun yener zayt lid, 73-74). Dedicated to the poet Yankev Glatshteyn, the poem was inspired by the eastern Canadian landscape and opens with an image of a local Indigenous chief, yet it unfolds into an expression of Jewish collective memory and mourning. Most of the poems in this section of the volume, subtitled "Mitbeymer un feygl" (With Trees and Birds), though inspired by Montreal's fall and winter landscapes, are devoid of specific urban markers and invoke only natural images of snow-covered fields and pine trees that could just as easily be attributed to the rural Polish landscape of the poet's youth. Korn exploits the similarity, deliberately blending descriptions of her current setting with the East European landscape embedded in her memory." Rachel Seelig, "Like a Barren Sheet of Paper: Rokhl Korn from Galician Orchards to Postwar Montreal," Prooftexts 34 (2014): 376n46.

\section{3}

Whitehead 2004, 66.

\section{4}

Whitehead 2004, 55. See also Jane Simington, Journey to the Sacred: Mending a Fractured Soul (Edmonton: Taking Flight International, 2003).

\section{5}

Whitehead 2004, 60.

\section{6}

Whitehead 2004, 50.

27

Whitehead 2004, 63.

\section{8}

Whitehead 2003, 275-276.

29

In the context of the rationalist-empiricist debates of the period, Immanuel Kant's famous "Copernican Revolution" postulated that what we see conforms to structures already existing in our mind. This was in stark opposition to the prevailing view that our mind shapes itself to that which is outside of it: "We can cognize of things a priori only what we ourselves have put into them" (Critique of Pure Reason 1787, xviii). In other words, knowledge of the visible world (not the unknowable noumenal world) is strongly correlated with our own internal perceptive lens.

\section{0}

Jean-Pierre's entanglement with Amalia in Chava Rosenfarb's “Last Love" entangles magic realism into Canadian landscape. In regard to this story Goldie Morgentaler comments that Canada "is bland neutral territory, which is nevertheless deadly, because its unflavoured ahistorical terrain, like a tabula rasa, permits the intrusion of a corroding European reality [...] Canada is the neutral land of refuge, which, like blank paper patiently permits the survivors to impose their past on its present" $(2003,45)$. Goldie Morgentaler, Goldie, "Chava Rosenfarb: The Yiddish Woman Writer in the Post-Holocaust World," in Canadian Jewish Studies 11 (2003): 37-51.

\section{1}

Eli Wiesel, Night (New York: Hill and Wang, 2006 [1958]), 10, 12, 17. See also Schama, 26.

32

Rhea Tregebov, "Elegy for the Given," in (alive): Selected and New Poems (Toronto: Wolsak and Wynn, 2004), 101.

\section{3}

Miriam Waddington, "Traffic Lights at Passover," in Mirror of a People: Canadian Jewish Experience in Poetry and Prose. Edited by Sheldon Oberman and Elaine Newton (Winnipeg, MN: Jewish Educational Publishers of Canada, 1985), 117-118.

\section{4}

Waddington, 91.

\section{5}

Whitehead 2004, 72. 